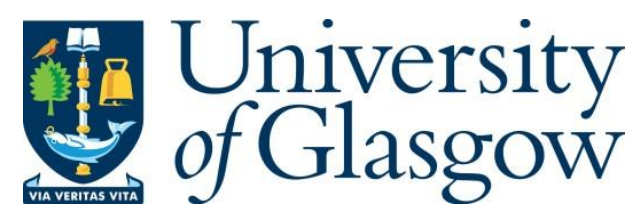

Kamete, A. Y. (2017) Governing enclaves of informality: unscrambling the logic of the camp in urban Zimbabwe. Geoforum, 81, pp. 76-86.

There may be differences between this version and the published version. You are advised to consult the publisher's version if you wish to cite from it.

http://eprints.gla.ac.uk/137683/

Deposited on: 6 March 2017

Enlighten - Research publications by members of the University of Glasgow http://eprints.gla.ac.uk 


\title{
GOVERNING ENCLAVES OF INFORMALITY: UNSCRAMBLING THE LOGIC OF THE CAMP IN URBAN ZIMBABWE
}

\author{
Amin Y Kamete \\ University of Glasgow
}

ARTICLE DETAILS AND LINK:

Kamete, A. Y. (2017). Governing Enclaves of Informality: Unscrambling the Logic of the Camp in Urban Zimbabwe. Geoforum, 81C(2017), 76-86. doi:10.1016/j.geoforum.2017.02.012

(C) 2017. This manuscript version is made available under the CC-BY-NC-ND 4.0 license http://creativecommons.org/licenses/by-nc-nd/4.0/

\begin{abstract}
The warehousing of informals in designated enclaves is a common strategy for the government of urban informality in the global South. In this article, I unscramble state-operated enclaves of informality in Zimbabwe. The article scrutinises two types of enclave: a flea market and a holding camp. I extend Agamben's politico-juridical construction to the social and economic realm. I question claims of inclusion in flea markets by juxtaposing a 'soft' zone of indistinction (flea market) with a 'hard' zone of indistinction (holding camp), arguing that both spaces are dump sites for homo sacer. I draw attention to the construction of bare life in both enclaves and emphasise the condition of rightlessness and the delimiting of the value of informals to bare life. Reflecting on the extent to which these spaces manifest the logic of the camp, I argue that both are spaces of exception.
\end{abstract}

Keywords: urban informality; bare life; Harare; planning; zone of indistinction; logic of the camp;

\section{Introduction}

A common spatial strategy for managing informals ${ }^{1}$ in urban sub-Saharan Africa involves relocating and/or confining them to special enclaves. The enclaves are officially designated spaces where informality is warehoused to achieve several goals: eliminating disorder, making informals contribute to public coffers, and modernising informal enterprises (Hansen, 2004; GoZ, 2005; Centeno and Portes, 2006; Tokman, 2007; see Cresswell, 1996). The establishment of these enclaves is a profoundly spatial strategy aimed at addressing a spatial problem. Ambulant informals on various contested spaces are seen as generating disorder primarily because they flout planning

\footnotetext{
${ }^{1}$ I use the term 'informals' as a shorthand term to refer to people who are directory involved in the informal economy and informal housing (cf. Bayat, 2004).
} 
and property laws. They have no legal right to occupy the contested spaces and they use them in ways that violate the diktats of planning (Kamete, 2008).

While the processes leading up to the designation and establishment of the enclaves, as well as the relocation of informals have been scrutinized, not much has been done in terms of clearly conceptualising the enclaves and investigating life in these spaces that the authorities and some commentators flag as proof of inclusive and accommodative policies for informality (see Kayuni and Tambulasi, 2009; Joseph, 2011). Rarely have claims of inclusivity and enablement been subjected to rigorous and critical scrutiny. This paper is an attempt to peer into this relatively underresearched and under-conceptualized dimension of an important phenomenon in sub-Saharan Africa.

Agamben's formulations are useful in this recasting. His notions of bare life, the camp, and the state of exception have been deployed in the study of a wide range of people. These include inmates of Nazi death camps (Agamben, 1998), illegal immigrants (Coleman, 2007; Pope and Garrett, 2012), military detainees (Comaroff, John, 2007; Brenkman, 2007), HIV-AIDS sufferers (Comaroff, Jean, 2007), undocumented workers (Ong, 2006), refugees (Downey, 2009; Zannettino, 2012) and asylum seekers (Darling, 2011). To this list this articles adds informals in governmentdesignated markets and informal settlements.

In this article I recast the relocation and confinement of informals and argue that, far from being an exercise in inclusion, the practice is an attempt at disablement and containment. Drawing on research in Zimbabwe, I scrutinize the warehousing of informals in a designated market and a holding centre. I work with Agamben's formulation and extend his politico-juridical construction to the social and economic realm in seemingly benign spaces of informality. Questioning claims of inclusion in flea markets, I juxtapose two sites of abandonment: a 'soft' zone of indistinction (flea market) with a 'hard' zone of indistinction (holding camp), arguing that both spaces embody the logic of the camp. I draw attention to the construction of bare life therein by emphasizing the pervasion of rightlessness and the delimiting of the value of informals to bare life.

In the next section I discuss Agamben's notion of the camp, pointing out that this provides a productive framework for reframing the practice of relocating and warehousing of informals. This 
is followed by a scrutiny of state-operated enclaves of informality in urban Zimbabwe. Finally, I argue for the recasting of these enclaves as the camp where bare life is produced and abandoned.

\section{Biopolitical sovereignty and the logic of the camp}

In southern Africa, the creation of enclaves where informals are settled and/or forced to confine their operations has received mixed reactions (Leduka, 2002; Hansen, 2010; Kamete, 2004). On one hand, the enclaves have been hailed as examples of inclusive planning; on the other, they have been dismissed as at best pointless gimmicks, or at worst, insidiously sinister structures of spatialized containment (see UN-Habitat, 2009; Kamete, 2014). The notion of biopolitics offers a productive intervention that could refresh this long-running debate.

First proposed by Foucault, and then radically interpreted by Agamben biopolitics can illuminate critical issues relating to enclaves of informality. Foucault (1998: 136) links the emergence of the modern state with 'the entry of phenomena peculiar to the life of the human species into the order of knowledge and power, into the sphere of political techniques'. This entry of biological life into political calculations marks a new form of power, biopower, which explicitly politicizes life, as opposed to sovereign power which 'operated on the principle of the right to commit its subjects to death in order to enhance the strength of the sovereign' (Mills, 2008: 59). For Foucault, there has been a transition from politics to biopolitics. He links this transition with attempts to govern populations - the administration of life (Mills, 2008: 59) - that began in the western world in the $17^{\text {th }}$ century (Dean, 1999). It is this version of politics that was exported to southern Africa (Kamete and Lindell, 2010; see Legg, 2007). The handling of informality takes on a new meaning if it is viewed through this lens of biopolitics: the style of government that regulates populations through 'biopower', taken here to mean the application and impact of political power on all aspects of human life.

The creation of special enclaves for the warehousing of informality is an exercise of biopower, a biopolitical act. Since these enclaves are fundamentally a spatialized response to informality, a useful intervention is to recast this strategy as one of the state's spatial technologies in the government of informality. Agamben's (1998) notion of the camp is particularly useful in this respect. It is helpful to discuss the camp in the context of the state of exception, a key feature of biopolitics, from which the camp is inseparable. Agamben $(2000: 38,41)$ observes that the camp 
was 'born out of the state of exception and martial law', which makes the camp the 'materialization of the state of exception'. For this reason, in this section I will discuss the two concepts together.

Described by Mills (2008: 5) as 'a paradigm of biopolitical sovereignty', the camp is 'the space opened when the exception becomes the rule or the normal situation' (Mills, 2005). To unscramble the camp, therefore, we need to understand the 'state of exception'. The incorporation of a dictatorial element within the constitution allows a government to act decisively, especially when there is need to combat (what it defines as) a crisis and to normalise the situation (Schmitt, 2014: 17; Cailleba and Kumar, 2008). The state of exception is a cornerstone of this element (Schmitt, 1985). It frees the state from any legal restraints to its power that would normally apply. This state is a situation when 'the juridical order is suspended' (Kisner, 2007: 222). This suspension is possible because of the special position of the government's as the sovereign, who, according to Schmitt (1985: 5), is 'he who decides on the state of exception'. Though belonging to the juridical order, the sovereign 'stands outside the normally valid legal system' (Schmitt, 1985: 7). As Agamben puts it, 'the sovereign, having the legal power to suspend the validity of the law, legally places himself outside the law' (1998: 15).

In the state of exception, questions of citizenship and individual rights can be diminished, superseded and rejected as the sovereign extends its power. Hence, the "citizen" disappears into a "bare life" over whose management the state has taken over and in which the rule of law is suspended' (Kisner, 2007: 223). The bare life into which the 'citizen' disappears is life stripped of form and value (Agamben, 1998; Diken and Laustsen, 2002). It is the form of life that is produced through the colonization or politicization of biological life $(z o \bar{e})$ 'by an increasingly elaborate skein of institutional structures and relationships which find their axiomatic expression in "law" and various manifestations of "sovereign power" (Gandy, 2006: 500).

The state of exception is crucial to understanding planning and the handling of informality by the sovereign. This is because of its spatialisation. According to Gandy,

The 'state of exception' takes on the form of a distinctive 'space of exception' whether reflected in the huddled communities beyond the walls of a medieval city or the marginalized belts of deprivation in the contemporary metropolis (2006: 500; emphasis added). 
The same can be said of the enclaves of informality. Interestingly, Roy notes that 'informality is the state of exception determined by the sovereign power of the planning apparatus' (Roy, 2005: 153). This is useful observation, for informality comprises 'unregulated activities in a political economy in which similar activities are regulated' (Roy, 2005: 156). Informality exists because the sovereign, who stands outside the juridical order, allows it to exist.

Described as the 'spatialization of the politics of exception' by Minca (2005: 412), the camp is the space resulting from the declaration of the state of exception: 'the space that appears when the state of exception becomes the rule and gains a permanent spatial form' (Minca, 2011: 41). Gandy (2006) provides useful insights into the rise of the camp. Citing Agamben, he explains that 'sovereign power involves a complex set of spatial relations between "outside and inside, the normal situation and chaos"' (page 501). This sees 'chaos' being incorporated into the juridical order (Gandy, 2006: 501). This incorporation is done 'through the creation of a zone of indistinction between outside and inside' (Agamben, 1998: 5). It is the zone of indistinction that finds a spatial expression in the camp.

Gandy notes that the camp exemplifies this 'absolute space of exception'. In the camp 'citizens are deprived of their rights and reduced to a state of bare life at the whim of a sovereign power' (p. 501). These references to the camp almost always refer to the 'extreme' camps: Nazi concentration camps, modern-day prisoner-of-war camps, refugee camps and detention centres for illegal migrants (see Minca, 2005; Diken and Laustsen, 2006; Rancière, 2004; Comaroff, Jean, 2007). Could we legitimately transpose such dark descriptions from these 'extreme' camps to enclaves of informality? The following cases from Harare suggest that we can. The important thing here is that, just as in the concentration camps, these enclaves are spaces of exception where the suspension of the law becomes localized (Pratt, 2005: 1055), and the exception becomes the norm (Agamben, 2005). It is the extent to which the sovereign is prepared to go in the suspension of the juridical order - and hence the intensity of the deprivation of rights - that marks the major difference between the two. The logic is the same; the difference is one of degree.

A Heideggerian distinction between the 'ontic' and the 'ontological' is helpful in illuminating Agamben's reasoning on the camp (Abbott, 2014: 23; Whyte, 2014). Agamben's formulation is primarily ontological. According to Abbott (2014: 20), Agamben's ontological method accounts for his hyperbole and "his tendency to pass over historical nuance". Unsurprisingly, compared to 
Foucault, his ontic reason is not as developed, leading to criticisms by social scientists (Whyte, 2013; Abbott, 2012). Emphasising this observation, Whyte (2014) argues, 'Agamben's claims are often lacking in empirical detail' leading to criticisms 'by those with a keener eye for "ontic" detail'. The same can be said of his formulation of the camp. The camp, as discussed in this paper is the ontic manifestation of the state of exception when it becomes the rule at an empirical level.

Despite its mobilisation by scholars in a variety of fields, Agamben's theorisation of spaces of exception and his notion of bare life have generated considerable debate and criticism. Agamben's formulation is accused of denying or devaluing the potential agency of those within the camp (Rhodes, 2005; Pittendrigh, 2015). These inhabitants are often presented as passive victims of sovereign abandonment, without agency or political identity. It seems there are no possibilities left for those that are 'literally caught in the categories and mechanisms of biopower' because 'the biopolitical trap seems impossible to circumvent' (Snoek, 2015: 136). In Agamben's formulations such as the spaces of exception and homo sacer, the possibilities for agency from the site of the excluded seems remote if not impossible (Bousfield, 2005: 3).

The deployment of Agamben's notions has also been questioned. In particular, the extension of the logic of the camp to all manner of new spaces (Diken and Laustsen, 2005) from refugee camps to famine relief camps (Edkins, 2000), raises questions about its meaningfulness and usefulness as a framework for analysis. It could legitimately be asked whether this notion's deployment in so many spaces and contexts renders it meaningless.

Though this paper does not aim to address criticisms of Agamben's formulations on agency, it does provide highlights of agency in the two enclaves. However, the primary purpose of the paper is to peer into the condition and experience of the camp, not reactions to it. That not so much space is devoted to agency is neither a trivialisation nor a denial of it. It just was not the original intention of the paper. The second criticism is a lot more interesting. Extensive use does not render the notion of the camp meaningless. This extension of the logic of the camp into the flea market and holding camp tells us two things.

First, it illustrates the adaptability of this logic and concept to new contexts and spaces. Second, as noted above, it tells us something about the logic of the camp itself and its politics. At the very least, it challenges our thinking of the camp, our interpretation of its practice, and our understanding 
of the inmates' experience of the camp. There is nothing new in stating that the camp is the place where law and order are suspended. But there is value in exposing the subtle permutations of the politics of inclusive exclusion and its application into seemingly mundane spaces such as flea markets and holding camps. This is especially the case when the warehousing of informality is celebrated as a manifestation of inclusiveness and the dehumanising conditions in some of these new spaces are interpreted in purely technical terms.

\section{Enclaves of informality in Zimbabwe}

Informality in urban Zimbabwe is a result of the regulation of space and economic activity inspired by the quest for modernity (Kamete, 2013a). Urban planning and 'the apartheid-type regulation of economic activity and labour flows' (Mhone, 1996: 1) had a two-fold impact. First, the racist economic policies impeded the growth of unregulated small scale activities. Second, planning regulations pathologised the spaces where unregulated activities took place (Kamete, 2013b). The result was the mushrooming of activities that fell afoul of the strict regulatory regime in many ways. They ignored modernist planning's diktats on the occupation and use of space and flouted a cocktail of laws and regulations relating to such aspects as taxation, labour, health, safety and environmental management (Kamete, 2004). This was not helped by the inability of the formal sector to create employment in sufficient numbers to meet demand. The post-independence avowedly socialist government removed the racist elements in the laws and regulations. However, it clung onto the modernist dream and retained the colonial regime's modernist planning and economic policies and practices (Kamete, 2008). The recession that followed the 1990 Economic Structural Adjustment Programme and the post-2000 economic meltdown accelerated the growth of informality in urban Zimbabwe (Bond and Manyanya, 2003; AEDI, 2009; Magure 2015).

In this section I discuss two enclaves of informality in Zimbabwe: a flea market at the periphery of the CBD and a holding camp outside the city. The material is gleaned from my long-running study of informality and contested urban spaces in Harare that began in 2003. When the research began in 2003, the original purpose was to assess the relationship between youth and the authorities in contested urban spaces. From 2005 the research was expanded and took two routes: the authorities' handling of informality and the responses of informal to government's handling of informality. This paper is a product of this second phase and looks at government's handling of informality. In 
addition to personal observation, the information is based on an ethnographic study of two Hararebased informals: Rudo and Mudza. This is complemented by semi-structured interviews with seven key informants including an activist, a council official, party militia, law-enforcement and security operatives and planners (Table 1). The research for this study took place between 2004 and 2010.

\section{Table 1. Profile of participants}

\begin{tabular}{|c|c|c|}
\hline Pseudonym & Profile & Dates \\
\hline Planner Mrs J & Town Planning Officer, central government & 20 December 2010 \\
\hline Rudo & Woman, age $27^{*}$, Vendor/Cross-border trader & $\begin{array}{l}\text { Various, between August } 2004 \text { and } \\
\text { December } 2010\end{array}$ \\
\hline Planner Mr M & Town Planning Officer, local authority & 15 August 2009 \\
\hline Mudza & $\begin{array}{l}\text { Man, age 33, resident of transit camp and } \\
\text { informal trader }\end{array}$ & $\begin{array}{l}\text { Various, between August } 2004 \text { and } \\
\text { December } 2010 .\end{array}$ \\
\hline $\operatorname{Dr} M$ & $\begin{array}{l}\text { Activist and disaster relief expert in a } \\
\text { humanitarian organization }\end{array}$ & 10 December 2010 \\
\hline Officer Mr Q & State security operative & 15 December 2005 \\
\hline Mr K & Harare City Council official & 18 December 2010 \\
\hline Bryne & Man, age 22 , Ruling party militia & 19 December 2009 \\
\hline Big Dhara & Man, age 33 , Ruling party militia & 19 December 2009 \\
\hline
\end{tabular}

* All ages as of December 2010

\section{The end of troubles?}

When I last talked to her in December 2010, Rudo ${ }^{2}$ was a 27-year old single mother. Before the infamous Operation Murambatsvina/Restore Order (OM/RO) - the 2005 nationwide militarized urban clean-up campaign (Tibaijuka, 2005; Potts, 2007; Kamete, 2007) that almost wiped out urban informality in Zimbabwe - she was both a cross-border trader and an ambulant vendor operating from various sites in downtown Harare. For housing, she rented a backyard shack in the highdensity, low-income residential suburb of Glen Norah B, having lost her late father's house in Warren Park D, in an inheritance dispute with her stepbrother. She started running a 'serious business' in 1994 at the age of 11, when she used to accompany her late mother - a vendor and cross-border trader - to work. When she completed her Ordinary and Advanced Level Education

\footnotetext{
${ }^{2}$ Unless indicated otherwise, all quotes are Rudo's (for MFM) and Mudza's (for Hopley Farm). All participants have been anonymized. For details see Table 1.
} 
- which she passed 'with clearly flying colours [sic]', thanks to her father's 'insistence and persistence' - she was, in her own words, 'already a serious and switched-on businesswoman'.

Rudo's life was steeped in informality 'through and through, from A to Z'. Her accommodation and livelihood were 'informally saturated from head to toe [sic]'. In addition to operating outside the purview of state regulations on housing and business, her cross-border trading venture had elements of criminality. Having failed to secure a passport of her own, she used her late sister's passport to travel to Zambia, Botswana, Malawi and Mozambique. From these countries, Rudo 'imported sought-after merchandise like clothes, electrical items and foodstuffs'. A large portion of her trade was illegal. She smuggled cigarettes out of Zimbabwe and smuggled a large proportion of her merchandise into the country. This she accomplished with the connivance of corrupt border officials as well as bus and truck drivers. It is little wonder that Rudo boasted in her perfect English that she was 'double informal and treble illegal'. Paradoxically, unlike many vendors, Rudo does have a hawker's licence - which legally allows her to trade. She 'inherited' it from her mother and religiously renews it every year.

The problem with Rudo has to do with the occupation and use of urban space. When she started, she held no title or lease for the numerous spaces she operated from: bus stops, road sides, shop fronts, car parks and public open spaces. Her occupation of the spaces was decidedly illegal, as she 'was never supposed to be there in the first place'. She used those spaces for purposes for which they were not zoned in the operative local plans. She used the spaces for business contrary to the legally stipulated uses as public spaces, open spaces, road reserves and bus shelters, among other uses. This is what made her life 'damn, very, very, difficult', putting her 'on a straight collision course' with the planning system backed by the Harare Municipal Police (HMP), the Zimbabwe Republic Police (ZRP) and the dreaded 'Riot Squad' (Kamete, 2008). In the 20 years she had been operating in Harare, she was arrested 52 times, 'an average of a whopping 2.6 times a year', she boasted. She had been injured 13 times and had lost her merchandise countless times. In 1999, due to repeated clean-up campaigns - which always resulted in injury and/or loss of merchandize Rudo was forced into a People's Market at Fourth Street Bus Terminus. ${ }^{3}$ Because of 'unbearably poor business', she only lasted two months and went back to her old ambulant ways. In June 2005,

\footnotetext{
${ }^{3}$ Informals who were forced to relocate to Fourth Street Bus Terminus nicknamed the place 'Force Street'.
} 
she was part of the 'filth' that was cleaned away by OM/RO. She 'surrendered and admitted defeat' and moved into the iconic Mupedzanhamo Flea Market (MFM). She rented a stall 'second-hand' from the wife of a 'very senior ngonjo' [cop]. At the time of the study she paid US\$70 per month. Rudo described life in MFA as being 'like a detention facility'.

MFM was established in 1991. Literally translated, Mupedzanhamo means 'that which ends troubles/poverty'4. They are good reasons to label Mupedzanhamo a camp à la Agamben. To begin with, the land was not properly zoned as a market in the old town planning schemes or new operative local development plan. The authorities went against the statutory plan and established a market anyway. According to Planner Ms J, the 'ostensible purpose' for establishing the market was 'to cater for hundreds of people who were being retrenched from their work' thanks to the World Bank-IMF imposed Economic Structural Adjustment Programme (ESAP). Be that as it may, whatever the original purpose for setting it up, MFM is the product of a state of exception.

Located away from the city centre, near the bustling high-density residential area of Mbare, the walled market is 'a shopping paradise for low-income people'. In the market 'you can buy chesechese chauneda [anything you want] ... - used clothes, cosmetics, food; you name it, it's here'. Rudo is always at pains to stress that she was forced into MFM 'against my every wish and business judgement $[s i c]$ '. The arrest, injuries and losses were enough to convince her to heed the authorities' demands to operate in legally designated markets - notwithstanding the glaring fact that MFM was technically illegal when it was set up. Compared to what she termed her 'business and social freedom' in the CBD, Rudo maintains that MFM is like 'one of those horrible Nazi things'. She explains,

\footnotetext{
${ }^{4}$ Shona: Kupedza - to end; nhamo - troubles/poverty.
} 
This place is not a happy business venue. If you spend your life here, you will see it is like Hitler's prisons - you know, one of those horrible ones - is it in Poland? Yeah, those ones. OK they don't bring you here in a crowded train ... but you come here against your will because you have no option. You can't be where you would rather be, so you are forced to come here. And when you are here, you experience true prison life - abuse, extortion, overcrowding, no hygiene, no rule of law, day in and day out. That is Mupedzanhamo for you. Zaa [prison] pure and simple.

Planner Mr M accused Rudo of 'overdramatizing the situation'. He opined, 'OK, it's not Wall Street or a glitzy shopping mall, but it still offers a place for making money. Isn't this the whole point of running a business?'

\section{'A Transitional hellhole'}

Also known as transit camps, in Zimbabwe, holding camps have been a favourite state strategy in handling urban informality since the 1980s. Some of the (in)famous transit camps include Porta Farm, Dzivaresekwa Extension and Hatcliffe Extension. So appalling are the conditions in the holding camps that they have been labelled as 'concentration camps' (Kamete, 2002). This section will look at a new type of camp, the post-2005 holding camps ostensibly established as temporary 'processing centres' for people displaced and detained in the wake of OM/RO.

Mudza is a 33-year old father of four. He grew up in an illegal backyard shack in National, a section of Mbare high-density low-income residential area. In February 1991, when Mudza was 14, his father was made redundant, thanks to ESAP. Unable to afford the rentals, the family moved to an informal settlement on the banks of the Mukuvisi River. His parents survived by selling odd items at Mbare Bus Terminus. Mudza, a secondary school dropout, joined the informal sector at the age of 16 and operated outside Siyaso Home Industry ${ }^{5}$, selling building materials. He had no licence as required by city bye-laws. In August of the same year, prior to the Commonwealth Heads of Government Meeting (CHOGM) scheduled for Harare in October, Mudza and his parents were among the thousands who were rounded up in a clean-up operation and forcibly relocated to a 'holding camp' at Porta Farm, some 40 kilometres from the city.

The disused farm was owned by Harare City Council (HCC). The eviction was carried out by HCC on the direction of the Ministry of Local Government and Housing. Mudza and other evictees were

\footnotetext{
${ }^{5}$ For a discussion of 'home industries' in Zimbabwe see Kamete (2004).
} 
assured by the authorities that their stay there would be temporary and that they would be permanently resettled elsewhere (see AI/ZLHR, 2006). The crowded farm was like a prison camp (Kamete, 2002). Apart from the 'constant surveillance by a paranoid state' (Dr M), the camp had no infrastructure, services or facilities. Mudza lived in a plastic shack with his parents. In 1997, at the age of 20 he married and moved out to start his own household in a nearby shack.

In 2005, during OM/RO Mudza was one of the thousands who were swept away in the campaign of eviction, demolition, detention, and sheer violence. Mudza's business at Siyaso was razed to the ground. Mudza and his family were carted off to Hopley Farm a 'holding centre', at the outskirts of Harare. Like Porta Farm, Hopley Farm was meant to be a 'transit camp'. According to the official line, people held there would be resettled and allocated proper houses. Before long Hopley Farm turned into what Mudza described as 'gehena rine chimoto chisingaperi' (hell with everlasting fire). Dr M, a disaster relief expert pointed out, 'If Porta [Farm] was a prison camp, then Hopley is a death camp. It's not a transitional camp. It's a transitional hellhole.'

Describing life at the Hopley settlement, Mudza said:

It is hell here, burning hell. Hapana chtsvene chiripo pano [There is nothing decent here]. There are no services, school, proper clinic . . roads, or clean water. There is no security for us. Life here is seen as worthless. It's worse than Chikurubi [maximum-security prison in Harare]. We are being watched like criminals. And whatever happens here - theft, injury, murder, death - you are wasting your time when you report it to the police. They guard the place, not to protect us, but to separate us from the world, to keep us invisible. Isusu totori muzaa manje [We are in prison for sure].

Officer Q, a garrulous university-trained security operative assigned to Hopley did not dismiss Mudza's accusations. He retorted, 'Well, what do you expect? It's not a hotel. For goodness' sake, we are running a holding camp for riff-raff, not the Sheraton [a five-star hotel in Harare]'.

\section{Uncovering the logic of the camp}

It is my argument that we can decipher the logic of the camp in the two enclaves in several aspects: the localisation of the state of exception, the production of bare life, precariousness and the multiplicity of 'sovereigns', including 'petty sovereigns' (Butler, 2004: 56), that the 'inmates' have to contend with. Individually, these pieces give a glimpse of the camp; taken together, they present a compelling case for characterising these enclaves as embodying and reflecting the logic of the camp. 
The location and appearance of the two enclaves reflect the spatiality of the camp. MFM is located on 'land that no business desires' (Planner Mrs J). It is at the margins of the CBD, close to condemned dilapidated flats in Mbare, 'an impoverished, decaying township' (Rudo), with a reputation for crime and violence. MFM was 'constructed opposite a graveyard on land that nobody wanted, ... which council had no use for' (Planner Mr M). The market is surrounded by a high wall on all sides. It is these spatial and design aspects that prompted Rudo to complain, 'This is a rubbish dump and a hell [sic]. It's like they want to trash us because we are rubbish, to flush us down the toilet because we are $\mathrm{s}^{* *}, \ldots$ to separate us sinners from their holy city.' It looks like distance and walls have been used to isolate 'riff-raff', to sever them from the modern city centre.

Hopley Farm is similar, if not worse. The holding camp is located eight kilometres from the outskirts of the city. There is no need for a wall here. In the early days it was guarded by state armed security agents. They may not be that visible now, but the settlement is 'under constant surveillance, every day, and every hour' (Mudza). The entry restrictions and the manhandling, arrest or ejection of unwanted outsiders and snoopers - such as journalists, foreigners, and activists - confirm this. The location makes it easy to localise the state of exception and to craft and enforce a surfeit of arbitrary restrictions. Here, there are virtually no freedoms to talk about. Rights of assembly, expression and association are non-existent 'unless it has something to do with ZANUPF [the ruling party]'. Dr M confirmed this, pointing out that 'anything not in the name of or to the advantage of the ruling party is banned'.

The most striking impression one gets is that the two enclaves are oppressively overcrowded. Rudo pointed out, 'Mupedzanhamo is a kombi [the often-crowded public transport]. Instead of 10 passengers it carries 18. And there is always room for one more.' This is exacerbated by primary tenants, who are often senior public officers or those connected to them, often illegally subdividing and subletting their stalls. In Rudo's case, the police officer's wife had subdivided her stall and sublet it to two second-hand tenants who paid her a monthly rental of US\$70. She paid the council US\$63. None of the officials I talked to knew how many people operated at MFM. 'This is like counting the wind,' Mr K admitted. The city, according to the official, was powerless to enforce the law because of 'high-ranking vested interests [sic]'.

Speaking about Hopley Farm, Mudza insisted it is 'a place that in the authorities' minds can never be full'. He is right. Hopley is 'a dumping ground of human waste' (Dr M). It is overcrowded, 
especially when one considers the number of 'inmates', the inhabited space and the level of infrastructure and services. And the authorities seem not to care how many people there are on the farm. How else can one explain the lack of interest in accurate numbers? One official said the number was 'somewhere between 6,000 and 8,000 - eh, 10,000 at the most' (Mr K). Highlighting this problem, Amnesty International (2010: 2) speculates that Hopley Farm 'has an estimated 5,000 residents' and then adds that 'there is no exact information of how many people reside at Hopley. ... [T] he real population figure may actually be higher' (page 20).

The overcrowding is accentuated by woeful service provision. There are 'no facilities to talk about' (Mr K) at MFM. A parliamentary committee that sought 'to understand the operations and challenges faced by [Small Medium Scale Enterprises]' concluded that the market was 'a health hazard' (Parliament of Zimbabwe, 2010). This is ironic, considering that in the first instance, cleanup operations - such as those that forced Rudo into the market - are invariably rationalized in terms of, among other things, sanitation, health and safety. According to the committee, the overcrowding and few toilets make 'the place susceptible to cholera'. This echoes Rudo's point that MFM is a 'ticking health time bomb'. The shortage of clean running water worsens the situation. It looks like the strict environmental, health and sanitation regulations that apply in the polis do not apply at MFM.

If MFM is 'a ticking time bomb' then Hopley is an improvised explosive device: crudely constructed and dangerous. Because of its location and the fact that it is both home and workplace, Hopley is worse than MFM in every respect. There is no potable water, no sanitation facilities, and, save for a makeshift clinic, there are no services to talk about. The temporary clinic was established by a humanitarian agency in 2005. HCC later took over the running of the facility. Mudza dismissed the clinic as being less than 'a first-aid kit that a medic brings to a football match'. One humanitarian agency described it as 'far from adequate ... with no running water and woefully inadequate sanitation facilities' (Amnesty International, 2010). It is little wonder that 'both ... [the mothers'] lives and the lives of their new-born babies are put at risk because of the government's failure to provide adequate levels of maternal and new-born care' (Amnesty International, 2010). The level of facilities falls far short of the city's planning standards, cementing Hopley's status as a space of exception (cf. Gandy 2006: 500). 
Abandonment by the sovereign exposes informals in both enclaves to extra-juridical violence, exploitation and abuse. Both MFM and Hopley have a multiplicity of 'sovereigns'. They include what Butler terms 'petty sovereigns' (2004: 56) that are 'delegated the authority to make the decision on the exception for the sovereign' (Jones, 2012: 687). In a state of exception, the 'sovereign' decision is made by the authorized person or institution on the ground: be it a soldier, a guard or the sovereign planning apparatus. At MFM, the presence of multiple sovereigns makes the conditions for traders, at best uncomfortable, and at worst dangerous. Central government is the ultimate sovereign. With its delegated authority, the city council is the 'operational sovereign'. Its officers frequent the place, as Rudo laments, 'not to make things better but to loot and terrorise ... left, right and centre'. As far as the city authorities are concerned 'rules can change overnight and they don't have to be civil about it' (Rudo). So it was that in 2011, the city authorities unilaterally decided to temporarily close the market 'for the sole purpose of rationalisation' (HRT, 2009). In the ensuing violence a person was killed when vendors and municipal police clashed. No one was charged for the killing.

The configuration of sovereignty is the same at Hopley. However, here central government has more direct control perhaps because the camp was established under its direction in exceptional circumstances. When I began the study in 2005, entry restrictions to outsiders and other internal controls originated from state operatives on the ground. As Mudza complained,

We are no better than prisoners here. Vasungwa vakatenge nani [prisoners are better off]. Prisoners, they know when they will be released. They know who is in charge, what their duties and powers, are and they have a clear chain of command. Not here. Angosvikawo netumasimba nechombo akutozviita mutongi [Whoever arrives with some powers and a weapon install themselves as rulers].

In MFM the petty sovereigns are the primary tenants - the 'landlords' to the majority of vendors who rent second-hand. These primary tenants, who rent stalls directly from council, are notorious for, as Rudo put it, 'making life difficult for you any day or time'. Rudo had her rent unilaterally raised four times in one year. At the time of the interview, the 'landlord' was 'threatening another rise'. The stall she was renting was her third one in less than a year having been summarily evicted from two stalls. According to Rudo, 'The landlord can evict you, push you around, extort you [sic] at any time, and there is nothing you can do about it. Here there is no rule of law to protect you, no human rights to talk about.' The situation is worse at Hopley. Petty sovereigns 'can lay claim to 
random patches' (Dr M) and exercise their sovereignty there. Extortion and harassment are commonplace. And there is 'nowhere to report to, ... nowhere to run for protection' (Mudza).

Significantly, militiamen belonging to ZANU-PF, have also become petty sovereigns in their own right, as have other violent party members. Confident that they can do anything with impunity, these petty sovereigns wreak havoc on traders. For example, they routinely ask vendors for ZANUPF membership, because to them, only party members have the right to conduct business at MFM. Not having the card 'is an invitation for a thorough beating' (Rudo) and there is no recourse to justice. Chipangano, a notorious violent fanatically pro-ZANU-PF Mbare-based outfit, prowls informal spaces in Harare. Perhaps because of its proximity to Mbare, MFM is 'their favourite hunting ground' (Rudo). Because ZANU-PF controls the police and security apparatus, 'these thugs can do what they want without anyone hindering or questioning them.... They run the show here' (Rudo). Rudo, who avowedly does not support any political party on religious grounds, has had to buy a party card after a series of threats, beatings, harassment, evictions and extortions. The card has bought her some reprieve from threats, but extortion and harassment continue.

Hopley has its own party militiamen who make life difficult for residents. Indicating the ease with which people become petty sovereigns in the camp, Mudza said, 'Just by having some position in ZANU-PF, you rule. You do what you want with people's lives. And nothing happens to you.' Unsurprisingly, in an environment of such sovereign impunity, beatings, harassment, evictions and extortions have become normal. During my last visit, Big Five a dreaded pro-ZANU-PF outfit was the chief petty sovereign. Made up of unemployed youths, Big Five 'frequently unleash[ed] a variety of terror tactics on inmates' (Dr M). The outfit regularly extorted 'contributions', levied a host of fees, and physically punished 'sell-outs' (non-party members). At times they destroyed shacks and subjected their victims to 'political re-education'.

The petty sovereigns in the two areas, in particular Chipangano and Big Five, are not mere opportunistic thugs. At MFM, two members of Chipangano openly boasted about the source of their authority. Bryne revealed that they had 'masimba [power] from musangano [the ruling party].' Saved in his mobile phone, which he referred to as 'a party cell phone', were contact details of three senior ruling party heavyweights - including a cabinet minister - and a number of secret service agents. 'We have authority to teach these people a lesson', he explained, 'because they 
voted wrongly.' At Hopley, Big Dhara, the leader of Big Five, invoked similar 'connections'. Officer Mr Q confirmed the claims, revealing he was their designated handler. Not surprisingly, a very senior ZANU-PF politician publicly 'admitted that her party uses the notorious Mbare-based militia, Chipangano' (Masvingise, 2012).

Significantly, both enclaves are characterised by the absence of mechanisms to regulate violence or abuse (see Shewly, 2013). It is little wonder that outcasts like Rudo and Mudza are perpetually exposed to, and have no recourse against, extra-juridical violence and abuse. Consequently, the value of the informals warehoused in the enclaves is delimited to a biological minimum (Agamben, 1998). Agamben (1998: 6) insists that the 'production of a biopolitical body is the original activity of sovereign power.' Bare life is a production of biopower. Since bare life is 'life shone of civic and political rights' (Comaroff, Jean, 2007: 209), we can legitimately claim that in the enclaves of informality - the spaces of exception - there is production of bare life. In both MFM and Hopley Farm, the state is seen dealing in 'the power to exclude, to suspend law, to strip human existence of civic rights and social value' (Comaroff, Jean, 2007: 209).

\section{On agency in the enclaves}

Though the paper is not about agency, the research did provide some insights on this in the two enclaves. As I argue below, the people warehoused in these enclaves are there because of what they do, which the authorities view as a threat to the modern city (Kamete, 2013a). The sovereign's intention is to neutralise these failed citizens. However, even after their 'legal and deserved containment' (Officer Mr Q), 'these people are far from 100\% neutralised' (Dr M). They continued to act and react in various ways. As noted by Officer Mr Q, the very presence and viciousness of the state's security apparatus and various restrictions was 'a manifestation of the unabated nuisance created by the problematic malcontents [sic]'. Incarceration did eliminate defiance, persistence and resistance (see Kamete, 2012a).

As Rudo put it, her 'longevity' as she described it, was a result of 'kukiya-kiya and knowing how to answer oppression'. Kukiya-kiya, as Jones (2010: 286) notes 'is a tricky word that suggests

\footnotetext{
${ }^{6}$ In 2000, ZANU-PF lost control of urban areas in national elections, a pattern that was repeated in

2002 - when it lost all major urban centres in local elections - and in 2005. In 2008, in addition to losing control of urban areas, the party lost its parliamentary majority, and for the first time, its candidate lost the presidential poll and was forced into a run-off. In 2009, the party was forced into an uneasy coalition government with the opposition.
} 
cleverness, dodging, and the exploitation of whatever resources are at hand, all with an eye to selfsustenance'. In Rudo's case, this included deception and resistance targeted at the 'land-lady' (the primary tenant), the sovereign and petty sovereigns. It also entailed deliberately disregarding the sovereign's edicts on such aspects as planning, health, safety, and taxation as well as subtly resisting the petty sovereigns' political manipulation. She admitted that there was 'also a lot of bribery and blackmail going on' (see below).

Mudza also used the term kukiya-kiya. Abandoned in the camp outside the city and "confined in a life-threatening environment" (Dr M), Mudza mused that survival in the camp required kuchenjera (being smart). This is not about confronting the authorities head-on and challenging their legitimacy or the legitimacy of their actions. Mudza's is what I have elsewhere termed 'resistance on the margins' (Kamete, 2010). Despite being confined and surrounded by petty sovereigns, Hopley Farm 'inmates' still managed to 'create and sustain a semblance of social, religious and commercial life' (Mr K), through such activities as church sessions, support groups, and entertainment. Notably, despite the security cordon, some enterprising 'businesspeople' occasionally broke the curfew and snuck outside to procure merchandise for resell. Mudza had a 'secret' musika [market] at his house, where residents could surreptitiously come and buy or borrow goods. According to Mudza, these 'survival activities' became possible 'through bribery and chikanari [chicanery]', some of it facilitated by 'middlemen' such as Dr M. Dr M himself noted that many of the petty sovereigns were "neither incorruptible nor entirely heartless". Confirming this, Bryne retorted, "Unofunga torarama sei? [How do you think we survive?]"

\section{Enclaves of containment}

In the literature, it is 'those excluded from citizenship ... who most fundamentally represent bare life in the exception' (Ellermann, 2009: 3). Could informals such as Rudo and Mudza possibly belong to the same class as enemy combatants, refugees, stateless persons, and illegal migrants? Diken and Laustsen (2002: 5) maintain that camps are exceptional spaces 'situated at the margins of the polis to neutralize its "failed citizens" or enemies' (Diken and Laustsen, 2002: 5). This is where informals such as Mudza and Rudo come in. They are deemed to be 'failed citizens' primarily because they neither live by the rules nor pay their dues (Centeno and Portes, 2006: 30). They are a danger to the polis (Kamete, 2012), hence the need to neutralise them through spatial, political and juridical strategies. 
Agamben (1998: 175) claims that the camp has become widespread, making it 'the hidden matrix of the politics in which we are still living'. To Agamben, 'the camp, which is now securely lodged within the city's interior, is the new biopolitical nomos of the planet' (1998: 176). The challenge is to learn to recognize 'this structure of the camp ... in all its metamorphoses' (page 175). The numerous permutations of officially designated enclaves of urban informality belong to these 'metamorphoses'. They are among the 'new camps ... [and] new and more lunatic regulative definitions of the inscription of life in the city' (Agamben, 1998: 176). As shown in the cases from Zimbabwe, the camp can appear anywhere the sovereign sees fit. Considering the state's singleminded obsession with eradicating informality, there is reason to claim that every one of the informals 'is at risk of being stripped of his or her legal protections and could be taken outside of the law at any moment' (Jones, 2009: 880).

As a sovereign spatial technology, the planning system plays a key role in the spatialisation and location of the state of exception. Contrary to some assertions, the designation of special enclaves for informals cannot be universally declared as a practice in inclusion (Kamete, 2013). It certainly does not amount to, as Planner Mrs J asserted, 'the recognition and embracement of the rights of vendors to earn a livelihood'. The preceding cases suggest that these enclaves can actually epitomize the withdrawal of rights to effect the sovereign ban (Agamben, 1998; Schaap, 2008). One might as well ask what rights are being recognized when people are forcibly confined in a place where the very nature of their business and its spatial characteristics and requirements are deliberately disregarded or supressed and the 'included' ones are consistently subjected to conditions of rightlessness. At any rate, the motive for the establishment of the enclaves has everything to do with order (see Bauman, 1993), and very little, if anything, to do with the rights or wellbeing of the people who end up dumped there (see Hansen, 2004). What we see in these enclaves is government using biopolitics 'to enforce who they want to see as their citizens, and to allocate access to economic and social benefits' (Biehl, 2005: 138). If anything, these enclaves are dump sites for outcasts (Selimović, 2006).

In the setting up of the camps, their management and the condition of the people in these spaces, it is tempting to acknowledge Schaap's synopsis of the ontological claims highlighted by Agamben which relate to 'the subject of politics (homo sacer), the relation between these subjects (the ban) and the space ... in which these subjects come together (the camp)' (2008: 1). The enclaves serve 
as production centres of bare life. By being placed in these enclaves, informals are abandoned. Each of the enclaves is the localisation of the state of exception. We witness the sovereign stepping outside its own planning laws and other regulations, sometimes in clear violation of the very regulations and ideals that are appealed to in the rationalisation of clean-up campaigns. In these enclaves, reference to order, safety, health, sanitation and hygiene is just smoke and mirrors.

In view of the evidence available, it may not be too farfetched to claim that bare life is produced in these enclaves. Ek (2006: 369) notes that 'the camp is a management technology best suited to the production of naked life on the threshold'. This is true of Hopley Farm, whose residents (read inmates) are just biological life, abandoned in subhuman conditions. Though put in that situation by the sovereign exercising its power, the inmates are not protected by the law once they are inside. Theirs is a clear-cut situation of rightlessness, where the bare life generated languishes in perpetual limbo as the transit camp becomes a permanent home (cf. Luban, 2003). On closer scrutiny, MFM embodies the same logic. It, too, is a dump site for outcasts.

Let us consider for a moment one key trait of the state of exception in the Nazi concentration camps. Because 'the camp was placed outside the law' - that is, was subject to a state of exception - 'the guards could punish the prisoners randomly, without taking any consequences for their acts' (Diken and Laustsen, 2002: 292). This is no different to the goings-on at both MFM and Hopley Farm where petty sovereigns terrorise informals with impunity. The similarities between the two enclaves suggest that the difference between the two is in the degree of abandonment (Nancy, 1993). The logic is the same. It can be argued that the flea market is a 'soft' zone of indistinction whereas the holding camp is a 'hard' zone of indistinction. While in both zones there is the same relationship between violence and law and similar processes of dehumanisation, in the 'soft' zone, the rightlessness experienced and the violence expressed are less extreme than in the 'hard' zone. In the former, abandonment is not a question of life or death. However, inmates in both camps are nether within the city nor completely outside it. Their fate is left to the sovereign decision.

Since the camp is the ontic expression of the ontological threshold all humankind is in, the logic of the camp extends beyond 'soft' and 'hard' zones exposed in this paper. As noted in this paper, the sovereign can easily reproduce the same logic in seemingly benevolent spaces such as airports and refugee camps. It does not take much to transform such spaces into malevolent enclaves. Although 
ontically, these 'spaces of domination' may be as different as refugee detention centres and death camps, 'they are ruled by the same metaphysical logic' (Abbott, 2012: 27).

The existence of these camps signifies the spatialisation of sovereign power and facilitates the production of bare life. Pope and Garrett note that the zone of exception in Agamben's formulation is narrow, which implies that 'the condition or the process to establish its creation is equally small, perhaps even as simple as bureaucratic necessity' (2013: 170). The operation of flea markets, which involves the sovereign suspending and dispensing with the law, confirms the lowering of this threshold.

When Zambian authorities hounded urban vendors into markets, in 1999, the official rationalisation was that 'the move to designated markets would situate vendors in an enabling work environment with necessary amenities ... that would enhance their security' (Hansen, 2004: 69). This mantra of enablement has been echoed ad infinitum in Zimbabwe and indeed throughout southern Africa. In view of the preceding analysis, it can be argued that disablement and containment have been the outcome- and perhaps the purpose - of these special enclaves. Spatial containment provides the ideal conditions for the production of bare life.

The camp is a spatialized materialisation of the differential treatment of segments of the population, what Ong terms graduated sovereignty (Ong, 2000). It shows biopolitics at work. As argued by Tagma (2009: 409), 'biopower has always needed sovereign exceptionalism to demarcate between those citizen-subjects who are domestic/domesticized subjectivities and those subjects who are to be cast outside'. It is this sovereign differentiation that creates graduated citizenship (Ong, 2006: 78) where citizens are administered according to their relevance to the objectives of the state. People seen as having value are nurtured, whereas those that are deemed to have no value are cast away as useless. The creation of enclaves of informality allows the state to accomplish this. Rudo and Mudza belong to the group that is seen as at best having no value and at worst a threat to the order desired by the sovereign. Hence, their relocation to the enclaves is in effect an act of abandonment and containment. It is when they are contained in these enclaves that they run the real danger of being reduced to bare life. 


\section{Empirical and theoretical contributions}

Apart from illustrating the adaptability of the logic of the camp to new contexts and spaces, the paper reveals something new and different about the logic of the camp itself and its politics in a particular context. The unscrambling of the logic of the camp in the two very different spaces of exception in a way challenges how we think of the camp and its practice in some contexts. While the logic of the camp outlined by Agamben is of use in unpacking the exclusionary practices of exception, containment and abandonment at play in the handling of informality by the authorities, there is nothing particularly novel about applying Agamben's notion of the 'camp' to new spaces.

Be that as it may, insights into the two camps make empirical/ontic contributions primarily in relation to research on informality in the global south as well as theoretical/ontological contributions in human geography more generally. The paper makes ontic contributions by peering into the concrete, specific realities of the enclaves of informality. It makes theoretical and empirical contribution by adding to and extending the application of Agamben's ontological formulation. First, empirically, as far as I am aware, at an ontic level, this is the first time the formulation has been comprehensively applied to the study of informality in the global South. Its contribution is not so much about adding to the formulation itself, but about interrogating the authorities' handling of informality through fresh and potentially productive lenses.

Secondly, the paper adds to studies that show that the production of bare life can go beyond aspects like race, ethnicity, nationality and religion. Many studies of the production of bare life emphasise the centrality of these aspects. Thus in Agamben's thesis, race is a key theme when he examines the camp, particularly the figure of the Muselmänner (the dying Jews) in the Nazi concentration camps (Agamben, 1999). Bauman (1989) similarly places emphasis on the centrality of race in the Holocaust. The same applies to Butler (2004) when she reflects on American policies governing the Iraq war, the treatment of Palestinians and the state of the Guantánamo prisoners.

In the two cases discussed here, there is a divergence from this. Race, religion or ethnicity are noticeably absent in the discourse on informality and the practices that it generates leading to the production of bare life. A secular 'black' government, dominated by the Shona ethnic group rules Zimbabwe. Christianity is the dominant religion. The largest ethnic group in Harare are the majority Shonas. The rest of the residents are mainly the minority Ndebele ethnic group, migrants 
from neighbouring countries, mixed race, Asian ('coloureds') and white. Notably, like Rudo and Mudza, the vast majority of people in the two zones are black, Christian, and Shona. As noted by Officer Q, in the official records of these failed citizens 'there are no boxes for sex, colour, tribe or church'. Mr K was quite emphatic that when dealing with informals 'hapana tsvete [there is no bias] tinotsvaira wese-wese [we sweep away everyone] who is out of line'.

What we witness is the perception of people as riff-raff not primarily because of who they are in terms of such aspects as race, religion and ethnicity, but because of what they do in terms of generating livelihoods and/or housing. Because of what they do, not only are they an obstacle to the modernist dream (Kamete 2013a), but they are also worthless. It is this perception that plays a central role in the designation of the spaces of exception and the production of bare life. The state is prepared to consign people who are 'essentially its own' (Dr M) in terms of race and ethnicity because they do not fit its definition of a useful citizen.

Third, in many studies of bare life, the camp and the state of exception, the bare life into which the citizen disappears is more or less a continuous condition. In Agamben's formulation, there is a clear relationship between inclusion and exclusion. As Lemke $(2005,5)$ observes, 'inclusion into a political community seems only possible by the simultaneous exclusion of some human beings who are not allowed to become full legal subjects'. The human beings who are consigned to the camps are abandoned in the camp. They are abandoned in the zone of indistinction indefinitely. This is not the case in Harare's MFM. Rudo is not permanently confined to MFM. She can, as she put it 'come and go ... walk in and out'. As soon as she leaves her stall and steps out of the camp, she merges into the citizenry, becoming 'just like any other respectable human being' (Rudo). This she does without staging a dramatic escape and being labelled a fugitive. Further, she can choose 'when to go in and when to come out'. It is when she is at work as an informal in the space of exception that she is reduced to bare life and her rights are stripped away. They are 'restored' when she steps out.

The situation was initially different for Mudza. For some time after it was set up, Hopley Farm was a no-go area, 'a serious security zone' (Officer Mr Q). Entry and movement were restricted. However, by the time the study ended, Mudza was in the same situation as Rudo. Just like Rudo, he could 'come and go'. As soon as he stepped out of Holey Farm, he became 'a person like other normal people' who could 'fit in with other people' and apparently claim the same rights that are 
enjoyed outside the camp. When back inside the camp, which he had to because, as he put it, 'this is my life and I have no choice', he was again reduced to bare life.

It should not be construed that the ability to 'come and go' gives them a choice. This is not how they see it. Rudo insists that she is tied to MFM because there is no choice. She pointed out:

I have to do what I do. When I do it, I become tsvina (filth). So every day I have to become tsvina. Do you think I like it? Do you think this is my choice? Nobody likes this label. You wouldn't like it, would you? So what makes you think I am different, ... that I have a choice?

The same can be said of Mudza. They both have no choice but to return to the spaces of exception time after time and do what they do for livelihood and/or housing. And each time they enter the camp they inevitably become tsvina and are inexorably reduced to bare life. But their abandonment is not indefinite.

Finally, the paper opens up possibilities of linking theories of bare life with theories of the formal and the informal. Discussion of the formal and informal have become richer than they were in the 1970s and 1980s. The creation of places for informality and the removal and confinement of people in these spaces is not something new (Brown, 2006). It has been the subject of much useful scrutiny from a variety of perspectives. But not much has been done by way of systematically theorising the nature of the spaces created for informality and the condition of the informals confined therein. The state-produced spaces where informals are confined are normally seen as normal spaces with normal rules. What does not work is often diagnosed in terms of lack of recourses, inappropriate planning, ill-conceived policies and strategies, or some other malady like incompetence and corruption (Roy and AlSayyad, 2004; Hansen, 2004; Setšabi, 2006; Tokman, 2007; Joseph, 2011).

This paper refreshes and enriches this debate by recasting these as spaces of exception (cf. Roy 2005), deliberately created by the state to warehouse failed citizens. By unscrambling the logic of the camp, it suggests the conditions in these spaces are not a symptom of some lack, poor policy, practices or negligence. They are the manifestation of a style of government that regulates populations through biopower. They are a spatialisation of the politics of exception which frees the state from any legal restraints to its power that would normally apply. To the extent that they make it possible for the state to neutralise failed citizens through spatial, political and juridical strategies, these spaces are a handy tool for the state. 


\section{Conclusion}

Strategies for 'accommodating' informal livelihoods in southern Africa revolve around relocating them to designated places: enclaves reserved for the confinement of undesirable people and activities. In this article, I have tried to recast these practices, arguing that they amount to the sovereign ban. Rather than the much vaunted enablement, they are an attempt at containment. Using cases from Zimbabwe, I have critically examined the designation, relocation and 'warehousing' of informality in a flea market and a holding camp. I have argued that in these enclaves of informality, characterized by a culture of exception, the logic of the camp is effectively normalized (Diken and Laustsen, 2005).

Described as 'Agamben's central concept of spatiality' (Diken and Laustsen, 2006: 443), the camp can open up productive avenues of enquiry in the government of informality. This is especially the case when we consider the establishment and governance of enclaves for the warehousing of informals and their activities. This article contends that "camp" does not only refer to the concentration camps of the Nazis or the contemporary urban ghettos; in principle it denotes every single space that systematically produces bare life' (Lemke, 2005: 6). When the sovereign steps outside its law to set up special enclaves and disregards a host of laws and regulations in the creation and governance of these enclaves, we are reminded of Agamben's thesis that 'the camp is the space that is opened when the state of exception begins to become the rule' (Agamben 1998: 168-9). This has happened at Hopley Farm and MFM.

It would be easy to point at the holding camp as a good example of the camp, and to dismiss the flea market as not making a perfect fit, for there is no clear-cut life-or-death issue here. My argument is that both spaces do reflect, in fundamentally similar ways, the logic of the camp. The discussion suggests that in the flea market and the holding camp, there are similarities in motivation (order, purity), process (sovereign ban; containment), modus operandi (localisation of state of exception; terror), condition of life (precariousness) and outcome (rightlessness, bare life). Both manifest the logic of the camp à la Agamben. Notably, both enclaves are characterised by the removal of protection by the law while being subject to that law (Shewly 2013:26), making them spaces of 'inclusive exclusion' (Agamben 1998: 27). The difference between the two is therefore one of degree. As such, both are zones of indistinction. Whereas Hopley farm is a 'hard' zone of indistinction, MFM is a 'soft' zone of indistinction. 
The point is that even unspectacular and 'un-extreme' enclaves, where the question is not necessarily about life and death, can count as spaces of exception. There are compelling reasons for the extension of Agamben's formulation to include enclaves where informals are abandoned. This makes sense, for today the production of bare life 'is gradually extended beyond the walls of the concentration camp ... as the inside/outside distinctions disappear' (Diken and Laustsen, 2002). In our fascination with the spectacular and sensational, we should not overlook the unspectacular and mundane. It is the seeming nondescriptness of the latter that makes them particularly insidious.

\section{References}

Abbott, M. (2012) No life is bare, the ordinary is exceptional: Giorgio Agamben and the question of political ontology. Parrhesia, 14: 23-36.

Abbott, M. (2014). The figure of this world: Agamben and the question of political ontology. Edinburgh University Press, Edinburgh.

AEDI (Africa Economic Development Institute). (2009). The failing state of Zimbabwe. AEDI Exclusives, 1(1), 1-3.

Agamben, G. (1998). Homo sacer: Sovereign power and bare life. Stanford University Press, Stanford, CA.

Agamben, G. (1999). Remnants of Auschwitz: The witness and the archive. Zone Books, New York.

Agamben, G. (2000). Means without end: Notes on politics. University of Minnesota Press, Minneapolis.

Agamben, G. (2005). State of exception. University of Chicago Press, Chicago.

AI/ZLHR (Amnesty International \& Zimbabwe Lawyers for Human Rights) (2006). Shattered lives - the case of Porta Farm. Amnesty International, London.

Amnesty International (2010). No chance to live new-born deaths at Hopley settlement, Zimbabwe. http://www.amnesty.org/en/library/info/AFR46/004/2006 (accessed 30.03.12). 
Bauman, Z. (1989). Modernity and the Holocaust. Polity Press, Cambridge.

Bauman, Z. (1993). Modernity and ambivalence. Polity Press, Cambridge.

Bauman, Z. (1995). Life in fragments: Essays in postmodern moralities. Wiley-Blackwell, Malden, MA.

Bayat, A. (2004). Globalisation and the politics of the informals in the global South. In A. Roy \& N. AlSayyad (Eds.), Urban informality: transnational perspectives from the Middle East, Latin America, and South Asia (pp. 79-102). Lexington Books, Lanham, MD.

Biehl, J. (2005). Vita: life in a zone of social abandonment. University of California Press, Berkeley, CA.

Bond, P., \& Manyanya, M. (2002). Zimbabwe's plunge: Exhausted nationalism, neoliberalism and the search for social justice. Merlin Press, London.

Bousfield, D. (2005). The logic of sovereignty and the agency of the refugee: recovering the political from 'bare life'. http://yorkspace.library.yorku.ca/xmlui/bitstream/handle/10315/1327/YCI0014.pdf (accessed 15.03.2016)

Brenkman, J. (2007). The cultural contradictions of democracy: political thought since September 11. Princeton University Press, Princeton, NJ.

Brown, A (Ed.) (2006), Contested spaces: Street trading, public space and livelihoods in developing countries. ITDG, Rugby.

Butler, J. (2004). Precarious life: the powers of mourning and violence. Verso, London.

Cailleba, P., and Kumar, R.A. (2008). Democratic statecraft versus political legitimacy: The case of Botswana. http://www.esc-pau.fr/documents/cahiers\%20recherche\%2008/cahier-10-art2.pdf (accessed 28.11.14).

Centeno, M.A., and Portes, A. (2006). The informal economy in the shadow of the state. In P. Fernandez-Kelly \& J. Shefner (Eds.), Out of the shadows: political action and the informal economy in Latin America (pp. 26-51). Pennsylvania State University Press, University Park, PA. 
Coleman, M. (2007). Immigration geopolitics beyond Mexico-US border. Antipode, 39(1), 54-76.

Comaroff, Jean. (2007). Beyond bare life: aids, (bio)politics, and the neoliberal order. Public Culture, 19(1), 197-219.

Comaroff, John. (2007). Terror and Territory: Guantánamo and the Space of Contradiction. Public Culture, 19(2), 381-405.

Cresswell, T. (1996). In placelout of place: geography, ideology and transgression. University of Minnesota Press, Minneapolis.

Darling, J. (2009). Becoming bare life: asylum, hospitality, and the politics of encampment. Environment and Planning D: Society and Space, 27(4), 649-665.

Dean, M. (1999) Governmentality: power and rule in modern society. Sage, London.

Diken, B and C.B. Laustsen (2005). The culture of exception: sociology facing the camp. Routledge, Abingdon.

Diken, B. and C.B. Laustsen (2002). Zones of Indistinction. Space and Culture 5(3), 290-307.

Diken, B. and C.B. Laustsen (2006). The camp. Geografiska Annaler: Series B, Human Geography 88(4), 443-452.

Downey, A. (2009). Zones of indistinction: Giorgio Agamben's 'bare life' and the politics of aesthetics. Third Text 23(2), 109-125.

Edkins, J. (2000). Sovereign power, zones of indistinction, and the camp. Alternatives: Global, Local, Political 25(1), 3-25.

Ek, R. (2006). Giorgio Agamben and the spatialities of the camp: an introduction. Geografiska Annaler: Series B, Human Geography 88(4), 363-386.

Ellermann, A. (2009). Undocumented migrants and resistance in the state of exception. http://aei.pitt.edu/33054/1/ellermann._antje.pdf (accessed 05.12.14).

Foucault, M. (1998). The history of sexuality 1: The will to knowledge. Penguin, London. 
Gandy, M. (2006) Zones of indistinction: bio-political contestations in the urban arena. Cultural Geographies 13(4), 497-516.

GoZ (Government of Zimbabwe) (2005). Response by Government of Zimbabwe to the Report by the UN Special Envoy on Operation Murambatsvina/Restore Order. Harare: Government Printer.

Hansen, K.T. (2004). Who rules the streets? The politics of vending space in Lusaka. In K.T. Hansen and M. Vaa (eds.), Reconsidering informality: perspectives from urban Africa (pp. 62-80). Nordiska Afrikainstitutet, Uppsala.

Hansen, K.T. (2010.) Changing youth dynamics in Lusaka's informal economy in the context of economic liberalization. African Studies Quarterly 11(2/3), 14-27.

HRT (Harare Residents Trust) (2009). 'Markets should be rationalised in Harare'. Press Statement, Harare, 19 September.

Jones, R. (2009) Agents of exception: border security and the marginalization of Muslims in India. Environment and Planning D: Society and Space 27(5), 879-897.

Jones, J.L. (2010). 'Nothing is straight in Zimbabwe': the rise of the kukiya-kiya economy 20002008. Journal of Southern African Studies 36(2), 285-299.

Jones, R. (2012). Spaces of refusal: rethinking sovereign power and resistance at the border. Annals of the Association of American Geographers 102(3), 685-699.

Joseph, M.C. (2011). Beyond modernist planning: understanding urban street vending in Botswana. http://www.rc21.org/conferences/amsterdam2011/edocs2/.../5-1-Molefe.pdf (accessed 20.06.13).

Kamete, A.Y. (2002). Transit or concentration camps? Revisiting state responses to urban homelessness in Zimbabwe. Paper presented at the E-Conference on Homelessness in Developing Countries, July 2002. CARDO, University of Newcastle upon Tyne, http://www.campus.ncl.ac.uk/cardo/virtualconf/asp/ (accessed 19.07.05). 
Kamete, A.Y. (2004). Home industries and the formal city in Harare, Zimbabwe. In K.T. Hansen and M. Vaa (eds.), Reconsidering informality: perspectives from urban Africa (pp. 120-137). Nordic Africa Institute, Uppsala.

Kamete, A.Y. (2008). Planning versus youth: stamping out spatial unruliness in Harare. Geoforum 3(5), 1721-1733.

Kamete, A.Y. (2010). Defending illicit livelihoods: youth resistance in Harare's contested spaces. International Journal of Urban and Regional Research 34(1), 55-75.

Kamete, A.Y. (2012a). Not exactly like the phoenix - but rising all the same: reconstructing displaced livelihoods in post-cleanup Harare. Environment and Planning D: Society and Space 30(2), 243-261.

Kamete, A.Y. (2012b). Interrogating planning's power in an African city: time for reorientation? Planning Theory 11(1), 66-88.

Kamete, A.Y. (2013a). On handling urban informality in southern Africa. Geografiska Annaler: Series B, Human Geography 95(1), 17-31.

Kamete, A.Y. (2013b). Missing the point? Urban planning and the normalisation of 'pathological' spaces in southern Africa. Transactions of the Institute of British Geographers 38(4), 639-651.

Kamete, A.Y. (2014). Perniciously integrated: reframing the 'integration' of the urban informal economy in southern Africa. http://eprints.gla.ac.uk/77200/ (accessed 17.06.14)

Kamete, A.Y. and I. Lindell (2010). The politics of 'non-planning' interventions in African cities: unravelling the international and local dimensions in Harare and Maputo. Journal of Southern African Studies 36(4), 889-912.

Kayuni, H.M. and R.I.C. Tambulasi (2009). Political transitions and vulnerability of street vending in Malawi. Theoretical and Empirical Researches in Urban Management 3(12), 79-96.

Kisner, W. (2007). Agamben, Hegel, and the state of exception. Cosmos and History: The Journal of Natural and Social Philosophy 2(2/3), 222-253. 
Leduka, R.C. (2002). Contested urban space: the local state versus street traders in Maseru's CBD West. Paper presented at the conference on Gender, Markets and Governance, Bamako, 7-12 September.

Legg, S. (2007). Beyond the European province: Foucault and postcolonialism. In J.W. Crampton and S. Elden (eds.), Space, knowledge and power: Foucault and geography. Ashgate, Aldershot.

Lemke, T. (2005). 'A zone of indistinction': a critique of Giorgio Agamben's concept of biopolitics. Outlines. Critical Practice Studies 7(1), 3-13.

Luban, D. (2002). The war on terrorism and the end of human rights. In M.V. Tushnet (ed.), The constitution in wartime: beyond alarmism and complacency. Duke University Press, Durham, NC.

Masvingise, W. (2012). 'Chipangano for hire: Muchinguri'. Newsday, Harare 5 June

Magure, B. (2015). Interpreting Urban Informality in Chegutu, Zimbabwe. Journal of Asian and African Studies, 50(6), 650-666.

Mhone, G. (1995). The impact of structural adjustment on the urban informal sector in Zimbabwe. Geneva: ILO.

Mills, C. (2005). Giorgio Agamben (1942-). Internet Encyclopedia of Philosophy. http://www.iep.utm.edu/agamben/ (accessed 24.05.12).

Mills, C. (2008). The philosophy of Agamben. McGill-Queen's University Press, Montreal.

Minca, C. (2005). The return of the Camp. Progress in Human Geography 29(4), 405-412.

Minca, C. (2011). Camp. In A. Murray and J. Whyte (Eds.), The Agamben dictionary (pp. 41-42).

Edinburgh: Edinburgh University Press.

Nancy, J.L. (1993). The Birth to Presence (Trans. Brian Holmes and others). Stanford, CA, Stanford University Press.

Ong, A. (2000). Graduated sovereignty in Southeast Asia. Theory, Culture \& Society 17(4), 55-75. 
Ong, A. (2006). Neoliberalism as exception: mutations in citizenship and sovereignty. Duke University Press, Durham, NC.

Parliament of Zimbabwe (2010). First report of the Portfolio Committee on Small and Medium Cooperative Development on the status of small and medium enterprises cooperative development in Harare. Harare: Parliament of Zimbabwe.

Pittendrigh, N. (2015). Making visible invisible suffering: Non-deliberative agency and the bodily rhetoric of Tamms Supermax prisoners. In K. Reiter \& A. Koenig (Eds.), Extreme punishment: Comparative studies in detention, incarceration and solitary confinement. (pp. 156-176). Palgrave Macmillan, London.

Pope, P.J., \& Garrett, T.M. (2013). America's homo sacer: Examining U.S. deportation hearings and the criminalization of illegal immigration. Administration \& Society, 45(2), 167-186

Pratt, G. (2005). Abandoned women and spaces of the exception. Antipode 37(5), 1052-1078.

Rancière, J. (2004). Who is the subject of the rights of man? South Atlantic Quarterly 103(2/3), 297-310.

Rhodes, L.A. (2005). Changing the subject: Conversation in supermax. Cultural Anthropology 20(3), 388-411.

Roy, A. (2005). Urban informality: toward an epistemology of planning. Journal of the American Planning Association 71(2), 147-158.

Roy, A., \& AlSayyad, N. (Eds) (2004). Urban informality: transnational perspectives from the Middle East, Latin America, and South Asia. Lexington Books, Lanham, MD.

Schaap, A. (2008). Political abandonment and the abandonment of politics in Agamben's critique of human rights. https://eric.exeter.ac.uk/repository/handle/10036/-

42438? show=full\&submit_simple=Show+full+item+record (accessed 14.11.11).

Schmitt, C. (1985). Political theology: four chapters on the concept of sovereignty. MIT Press, Cambridge, MA. 
Schmitt, C. (2014). Dictatorship: from the origin of the modern concept of sovereignty to proletarian class struggle (trans. by M. Hoelzl and G. Ward). Polity Press, Cambridge.

Selimović, I. (2006). Vita: life in a zone of social abandonment (book review). Arizona Journal of Hispanic Cultural Studies, 10, 299-301.

Setšabi, S. (2006). Contest and conflict: governance and street livelihoods in Maseru, Lesotho. In A. Brown (Ed.), Contested spaces: Street trading, public space and livelihoods in developing countries (pp. 131-152). Rugby: ITDG

Shewly, H.J. (2013). Abandoned spaces and bare life in the enclaves of the India-Bangladesh border. Political Geography 32 (1), 23-31.

Snoek, A., \& Fry, C.L. (2015). Lessons in biopolitics and agency: Agamben on addiction. The New Bioethics 21(2), 128-141.

Tagma, H.M. (2009). Homo sacer vs. homo soccer mom: reading Agamben and Foucault in the war on terror. Alternatives: Global, Local, Political 34(4), 407-435.

Tokman, V.E. (2007). Modernizing the informal sector. DESA Working Paper No. 42. United Nations Department of Economic and Social Affairs, New York.

UN-Habitat (2009). Planning sustainable cities: Global Report on Human Settlements, 2009. Earthscan, London.

Whyte, J. (2013). Catastrophe and redemption: the political thought of Giorgio Agamben. SUNY Press, Albany.

Whyte, J. (2014). Review of Mathew Abbott's The Figure of this World: Agamben and the Question of Political Ontology. Notre Dame Philosophical Reviews. http://ndpr.nd.edu/news/52792-the-figure-of-this-world-agamben-and-the-question-of-politicalontology/ (accessed 10/02/2017)

Zannettino, L. (2012). From Auschwitz to mandatory detention: biopolitics, race, and human rights in the Australian refugee camp. The International Journal of Human Rights, 16(7), 1094-1119. 